\title{
Virucidal activity of Haemaphysalis longicornis longicin P4 peptide against tick-borne encephalitis virus surrogate Langat virus
}

Melbourne Rio Talactac ${ }^{1,2,6}$, Kentaro Yoshii ${ }^{3}$, Hiroki Maeda ${ }^{1,2}$, Kodai Kusakisako ${ }^{1,2}$, Emmanuel Pacia Hernandez ${ }^{1}$ Naotoshi Tsuji ${ }^{4}$, Kozo Fujisaki ${ }^{5}$, Remil Linggatong Galay ${ }^{7}$, Tetsuya Tanaka ${ }^{1,2}$ and Masami Mochizuki ${ }^{1,2^{*}}$

\begin{abstract}
Background: Longicin is a defensin-like peptide, identified from the midgut epithelium of hard tick Haemaphysalis longicornis. Several studies have already shown the antimicrobial and parasiticidal activities of longicin peptide and one of its synthetic partial analogs, longicin P4. In this study, longicin peptides were tested for potential antiviral activity against Langat virus (LGTV), a tick-borne flavivirus.

Methods: Longicin P1 and P4 peptides were chemically synthesized. Antiviral activity of the longicin peptides against LGTV was evaluated through in vitro virucidal assays, wherein the antiviral efficacy was determined by reduction in number of viral foci and virus yield. Additionally, longicin P4 was also tested for its activity against human adenovirus, a non-enveloped virus. Lastly, to assess the importance of longicin on the innate antiviral immunity of $\mathrm{H}$. longicornis ticks, gene silencing through RNAi was performed.

Results: Longicin P4 produced significant viral foci reduction and lower virus yield against LGTV, while longicin P1 failed to demonstrate the same results. Conversely, both longicin partial analogs (P1 and P4) did not show significant antiviral activity when tested on adenovirus. In addition, longicin-silenced ticks showed significantly higher virus titer after 7 days post-infection but a significantly lower titer was detected after an additional 14 days of observation as compared to the Luc dsRNA-injected ticks. Mortality in both groups did not show any significant difference.

Conclusion: Our results suggest that longicin P4 has in vitro antiviral activity against LGTV but not against a non-enveloped virus such as adenovirus. Likewise, though most cationic antimicrobial peptides like longicin act directly on target membranes, the exact mechanism of membrane targeting of longicin P4 in enveloped viruses, such as LGTV, requires further investigation. Lastly, while the in vitro virucidal capacity of longicin P4 was confirmed in this study, the role of the endogenous tick longicin in the antiviral defense of $\mathrm{H}$. longicornis against LGTV still remains to be demonstrated.
\end{abstract}

Keywords: Antimicrobial peptide, Longicin P4, Langat virus, Haemaphysalis longicornis

\footnotetext{
* Correspondence: masamimochizuki@gmail.com

'Department of Pathological and Preventive Veterinary Science, The United

Graduate School of Veterinary Science, Yamaguchi University, Yoshida,

Yamaguchi 753-8515, Japan

${ }^{2}$ Laboratory of Infectious Diseases, Joint Faculty of Veterinary Medicine,

Kagoshima University, 1-21-24 Korimoto, Kagoshima 890-0065, Japan

Full list of author information is available at the end of the article
} 


\section{Background}

Ticks are hematophagous arachnids capable of transmitting several disease-causing pathogens in domestic and wild animals, including humans [1, 2]. As carriers of several pathogenic microorganisms, protozoa, rickettsiae, spirochaetes, and viruses [3, 4], ticks need to employ broad spectrum innate immunity mechanisms that will allow them to maintain the pathogens and commensal microbes without impairing their viability and further development $[2,5]$. As previously demonstrated, antimicrobial proteins and peptides play a major role in protecting ticks against microorganisms $[6,7]$.

Antimicrobial peptides are ancient immune molecules that are important in invertebrate and vertebrate host defenses $[8,9]$. These peptides display broad-spectrum biological activity against bacteria, yeast, fungi, protozoan parasites and enveloped viruses [10-12] and have been demonstrated to possess immunomodulatory properties [13]. Numerous small molecules such as defensins, lysozymes or by tick-specific antimicrobial compounds such as microplusin provide the direct antimicrobial defense in ticks [2].

Longicin, a defensin-like peptide identified from the midgut epithelium in the hard tick Haemaphysalis longicornis, is a promising cationic antimicrobial peptide. Many studies have shown that longicin and one of its synthetic partial analogs (longicin P4) have antimicrobial, fungicidal, and parasiticidal properties [5, 14, 15]. Thus, making them attractive molecules to be used as therapeutic agents, not only against tick-borne pathogens, but also to important human and animal diseasecausing agents. On the other hand, interest in the therapeutic applications of antimicrobial peptides or their synthetic analogues is increasing due to the rise in resistance to commonly used antibiotics $[4,16]$.

Tick-borne flaviviruses (TBFVs) cause considerable disease and death worldwide, wherein infections are characterized by mild to severe neurological symptoms, such as meningitis and encephalitis [17, 18]. For Europe, Russia and up to the eastern coast of Japan, tick-borne encephalitis virus is considered as one of the most medically important arboviruses with 10,000 to 15,000 cases recorded each year $[18,19]$. Since most TBFVs require at least a biosafety level 3 (BSL3) containment facility, the use of the naturally attenuated Langat virus (LGTV) provides a convenient BSL2 model of tick-borne encephalitis virus (TBEV) and other highly pathogenic TBFVs [17]. In this study, we investigated the virucidal activity of longicin P4 against LGTV, a member of TBEV serocomplex of the Flaviviridae family.

\section{Methods}

\section{Cell culture and virus}

Baby hamster kidney (BHK-21) cells (ATCC CCL-100) were maintained in Eagle's minimum essential medium
(EMEM) (Wako, Japan) containing $10 \%$ fetal bovine serum (FBS) (Equitech, USA) and $1 \%$ antibiotic/antimycotic (Nacalai Tesque, Japan), while HeLa cells (ATCC CCL-2) were maintained in Dulbecco's modified Eagle's medium (DMEM) (Nissui Pharmaceutical Co., Japan) supplemented with $10 \%$ FBS, $1 \%$ antibiotic/antimycotic and $1 \%$ L-glutamine (Wako, Japan). Both cells were maintained at $37{ }^{\circ} \mathrm{C}$ under $5 \% \mathrm{CO}_{2}$ until use.

The LGTV TP21 used in this study was amplified in $\mathrm{BHK}$ cells and the virus stock titer was determined by focus forming assay as previously described [20] with some modifications. Briefly, serial 10-fold dilutions of the virus stock were plated on $1 \times 10^{5}$ cells/well of BHK21 cells in 24-well plates. The infected cells were overlaid with $1.5 \%$ methylcellulose containing modified Eagle's medium (MEM) (Gibco, USA) with $1 \%$ FBS and $1 \%$ antibiotic/anti-mycotic. Viral foci were detected by a primary antibody against Langat virus surface proteins (hyper immune mouse polyclonal IgG) followed by Alexa Fluor 488 goat anti-mouse IgG (Invitrogen, USA), 3-4 days post-infection (dpi). The number of foci was counted using a fluorescence microscope and the titer of virus stock was expressed as Foci-Forming-Unit (FFU). The virus stock was then aliquoted and stored at $-80{ }^{\circ} \mathrm{C}$.

Human adenovirus 25 (ATCC VR-1103) was propagated in HeLa cells and the virus stock titer was quantitated by a $50 \%$ tissue culture infectious dose $\left(\right.$ TCID $\left._{50}\right)$ assay as previously described [21] with some modifications. Briefly, serial 10-fold dilutions of the virus stock were plated (eight wells per dilution) on $1 \times 10^{4}$ cells/well of HeLa cells in 96-well plates. Cytopathic effect was scored 6-7 dpi. The $\mathrm{TCID}_{50}$ was calculated as the inverse of the dilution at which $50 \%$ of the wells showed cytopathic effect, calculated by the method of Reed \& Muench [22].

\section{Ethical approval}

The use of the animals in our experiments was in accordance with the approved guidelines from Animal Care and Use Committee of Kagoshima University (approval number VM 13007).

\section{Ticks and animals}

Adult parthenogenetic (Okayama strain) H. longicornis ticks were used in this study. These ticks were maintained for several generations by feeding on the ears of Japanese white rabbits (Kyudo, Kumamoto, Japan) at the Laboratory of Infectious Diseases, Joint Faculty of Veterinary Medicine, Kagoshima University, Kagoshima, Japan. The rabbits were solely used for tick feeding and were not infected with any virus at any point during the conduct of this study. 


\section{Peptides}

Peptides were synthesized using a Perkin-Elmer Applied Biosystems 431 A Synthesizer with prederivatized polyethylene glycol polystyrene arginine resin (Sigma Genosys, Ishikari, Japan) and double coupling for residues. The reduced peptides were purified using reverse HPLC. The partial peptides are as follows: longicin P1 (QDDESDVPHVRVRRG 15 mer, Mw: 1764.8, pI: 5.43) and longicin P4 (SIGRRGGYCAGIIKQTCTCYR 21 mer, Mw: 2306.7, pI: 9.50). Peptide purity and integrity were assessed by MALDI-TOF Mass. The peptides were dissolved in normal saline $(0.85 \% \mathrm{w} / \mathrm{v}$ of $\mathrm{NaCl})$ with a final concentration of $1 \mathrm{mmol} / \mathrm{ml}$. The solutions were stored at $-30{ }^{\circ} \mathrm{C}$ until use [15].

\section{Cell proliferation assay}

The CellTiter $96^{\circ}$ Non-Radioactive Cell Proliferation Assay System (Promega, USA) was used to examine the toxicity of longicin P1 and P4 peptides on BHK-21 cells as per manufacturer's instructions. In brief, BHK-21 cells grown in EMEM were harvested and resuspended in a fresh medium at a final concentration of $1 \times 10^{5}$ cells $/ \mathrm{ml}$. Fifty microliters of the cell suspension was dispensed into each well of a 96-well microtiter plate containing an equal volume of either the 2-fold serially diluted longicin P1 and P4 peptides or only the growth medium. After $72 \mathrm{~h}$ of incubation, dye solution was added to each well followed by $4 \mathrm{~h}$ of additional incubation. The reaction was then stopped by adding a solubilization solution, and absorbance was recorded at $570 \mathrm{~nm}$ in a microplate reader. Cytotoxicity was expressed as the percentage inhibition of cell growth (\%) and was calculated as follows: Percentage cell growth inhibition $(\%)=(1-\mathrm{A} / \mathrm{B}) \times 100$, where $\mathrm{A}$ and $\mathrm{B}$ represent the absorbance value in the presence or absence of the peptide [14].

\section{Focus formation unit reduction assay}

Antiviral activity of longicin peptides was determined by measuring the reduction in the number of viral foci. Briefly, BHK-21 cells were prepared in 24-well plates $\left(1 \times 10^{5}\right.$ cells $\left./ \mathrm{ml}\right)$. The infected cells were overlaid with $1.5 \%$ methylcellulose containing MEM with $1 \%$ FBS. Viral foci were detected by a primary antibody against Langat virus surface proteins (mouse polyclonal IgG) followed by a secondary antibody (Alexa Fluor 488 goat anti-mouse IgG), three to four dpi. The number of foci was counted using a fluorescence microscope and the titer of virus was expressed as foci-forming-unit (FFU). The baseline for medium-treated infected cells was the mean of the viral foci number \pm SD. Then the percentage of foci reduction (RF\%) compared to medium-treated cells was calculated as follows: $R F(\%)=(C-T) \times 100 / C$. Where, $\mathrm{C}$ is the mean of the number of foci in medium- treated wells (without peptide) and $\mathrm{T}$ is the mean of the number of foci in peptide-treated wells [23].

\section{Virucidal assay}

Extracellular anti-LGTV activity of longicin P1 and P4 peptides was investigated by incubating 0.01 multiplicity of infection (MOI) of LGTV suspension with $1.25 \mu \mathrm{M}$ longicin $\mathrm{P} 1$ or $\mathrm{P} 4$ for $2 \mathrm{~h}$ at $37{ }^{\circ} \mathrm{C}$. For each assay, an EMEM-treated LGVT and an EMEM only control culture were included. Then, BHK-21 cells in 24-well plates were infected with the treated viral suspension for $1 \mathrm{~h}$ at $37^{\circ} \mathrm{C}$. Cells were washed with PBS to remove the unadsorbed viruses. Then, the plates were incubated at $37{ }^{\circ} \mathrm{C}$ for $3-4$ days. Antiviral activity was determined by the reduction in number of viral foci [23]. For the dose-dependent virucidal assay, LGTV was treated with two-fold dilutions of longicin P4 starting from 0.16 to $2.5 \mu \mathrm{M}$ for $2 \mathrm{~h}$ at $37^{\circ} \mathrm{C}$. On the other hand, to determine the time-dependent effect of longicin P4, LGTV was treated with $1.25 \mu \mathrm{M}$ at different exposure times $(0,15,30,60,120,240 \mathrm{mins})$ at $37{ }^{\circ} \mathrm{C}$. Foci forming unit reduction assay was used to determine the dose- and time-dependent antiviral effects of longicin P4 peptides.

The virucidal activity of longicin P4 was also tested against a non-enveloped virus by incubating 10 TCID $_{50}$ of adenovirus suspension with $1.25 \mu \mathrm{M}$ of longicin P1 or $\mathrm{P} 4$ for $2 \mathrm{~h}$ at $37{ }^{\circ} \mathrm{C}$. For this assay, a DMEM-treated LGVT and a DMEM only control culture were included. Then, HeLa cells in 24-well plates were infected with the treated viral suspension for $1 \mathrm{~h}$ at $37{ }^{\circ} \mathrm{C}$. Cells were washed with PBS to remove the unadsorbed viruses. The microplate was then incubated at $37{ }^{\circ} \mathrm{C}$ and observed daily under inverted microscope until CPE was more than $50 \%$ in the virus group. Images were taken 6-7 days post-infection and at same time, respective supernatants were collected for titration.

\section{Prophylactic antiviral assay}

The prophylactic antiviral assay was performed by treating BHK-21 cells in 24-well plates with EMEM or $1.25 \mu \mathrm{M}$ of longicin $\mathrm{P} 1$ or $\mathrm{P} 4$ for $2 \mathrm{~h}$ at $37^{\circ} \mathrm{C}$ prior to virus infection. After washing with PBS, cells were infected with 0.01 MOI of LGTV for $1 \mathrm{~h}$ for virus adsorption. Then cells were washed by PBS and overlaid with $1.5 \%$ methylcellulose containing MEM with $1 \%$ FBS. After 3-4 dpi, the antiviral activity was determined by foci reduction as described above [23].

\section{Post-adsorption antiviral assay}

The antiviral activity of longicin peptides against intracellular replication of LGTV was performed by treating BHK-21 cells in 24-well plates with EMEM or $1.25 \mu \mathrm{M}$ of longicin P1 or P4 after virus adsorption of $0.01 \mathrm{MOI}$ of LGTV for $1 \mathrm{~h}$ at $37{ }^{\circ} \mathrm{C}$. Unadsorbed viruses were 
washed with PBS and then the cells were treated with medium or $1.25 \mu \mathrm{M}$ of peptides for 3-4 days. Antiviral activity was determined by viral foci reduction assay as described above [23].

\section{Virus yield reduction assay}

Briefly, BHK-21 cells in 24-well plates were infected at a MOI of 0.01 with the LGTV pre-treated with longicin $\mathrm{P} 1, \mathrm{P} 4$ or medium for $2 \mathrm{~h}$ at $37^{\circ} \mathrm{C}$. After $1 \mathrm{~h}$ of viral adsorption at $37{ }^{\circ} \mathrm{C}$, cells were washed with PBS to remove the unadsorbed viruses and consequently replaced with EMEM with $1 \%$ FBS. Three days post-infection, supernatant from the infected cells were collected for titration [24].

For the adenovirus virucidal assay, virus yield was quantitated by a $50 \%$ tissue culture infectious dose $\left(\mathrm{TCID}_{50}\right)$ assay. Briefly, HeLa cells infected with adenovirus, which were previously treated with longicin P1, P4 and medium were sampled at $7 \mathrm{dpi}$. Supernatants were harvested and centrifuged to remove debris. Serial 10-fold dilutions of the supernatants were plated (five wells per dilution) on $1 \times 10^{4}$ cells/well of HeLa cells in 96-well plates. Cytopathic effect was scored 6-7 days post-infection. The $\mathrm{TCID}_{50}$ was calculated as the inverse of the dilution at which $50 \%$ of the wells showed cytopathic effect, calculated by the method of Reed and Muench [22].

\section{RNA interference (RNAi) and subsequent virus challenge}

The PCR primers used for the synthesis of doublestranded RNA (dsRNA) are listed in Table 1. The longicin fragments were amplified by PCR from cDNA clones using oligonucleotides including T7-forward and T7-reverse primers to attach the $\mathrm{T} 7$ promoter recognition sites on both the forward and reverse ends. The firefly luciferase $(L u c)$ was amplified from a vector DNA of pGEM-luc (Promega, Madison, WI, USA) through PCR using oligonucleotides containing T7-forward and T7-reverse primers. PCR products were purified using the GENECLEAN II kit (MP Biomedicals, Ohio, USA). The T7 RiboMAX Express RNA System (Promega) was used to synthesize dsRNA by

Table 1 List of PCR primers used for the synthesis of double-stranded RNA

\begin{tabular}{ll}
\hline Primer name & Primer sequence \\
\hline Longicin RNAi forward & CCTCATCTTCGTCCTTGTAG \\
Longicin RNAi reverse & ATTATGACGACACACATAAT \\
Longicin T7 forward & GGATCCTAATACGACTCACTAT \\
Longicin T7 reverse & GGCCTCATCTCGTCCTTGTAG \\
LuC T7 forward & GGATTATGACGACACACACATAATA \\
& GTAATACGACTCACTATAGGG \\
LuC T7 reverse & GTCCATCTTCCAGGATACG \\
& GTCCACACAACACACACTATAGGCACTCCTCC \\
\hline
\end{tabular}

in vitro transcription following the manufacturer's protocol. Successful construction of dsRNA was confirmed by running $0.5 \mu \mathrm{l}$ of the dsRNA products in a $1.5 \%$ agarose gel in a TAE buffer. Microinjection of dsRNA was performed as previously described [25]. Briefly, $1 \mu \mathrm{g}$ of longicin dsRNA in $0.5 \mu \mathrm{l}$ of distilled water was injected into the hemocoel of unfed adult female ticks through the fourth coxae, while Luc dsRNA was injected in the control group. A total of 92 ticks per group were injected. After injection, the ticks were held for $18 \mathrm{~h}$ in a $25^{\circ} \mathrm{C}$ incubator to check for mortality resulting from possible injury during injection. To initially confirm gene-specific silencing, 3 ticks from each group were collected at 0 and 4 days after injection (dai), and then total RNA was prepared for RT-PCR. RNA extraction was performed as previously described [25] and PCR was carried out using longicin and actin gene-specific primers (Table 2). PCR products were subjected to electrophoresis in $1.5 \%$ agarose gel in a TAE buffer, and bands were visualized after staining the gel with ethidium bromide using Quantity One 1-D Analysis Software (Quantity One Version 4.5, Bio-Rad Laboratories, Milan, Italy). Positive confirmation of longicin silencing was monitored until 60 dai of longicin dsRNA.

To further check the longicin gene silencing efficiency, expression analysis of the longicin mRNA was also performed through real-time PCR using THUNDERBIRD ${ }^{\mathrm{m}}$ SYBR $^{\circ}$ qPCR Mix (TOYOBO) with a 7300 real-time PCR system (Applied Biosystems), as previously described [26]. Briefly, gene-specific primers were designed to target the $H$. longicornis longicin and ribosomal protein L23 (internal control) genes, as shown in Table 3. Four-fold serial dilutions of cDNA of adult ticks were used to generate standard curves. The real-time PCR conditions were as follows: $95{ }^{\circ} \mathrm{C}$ for $10 \mathrm{~min}, 40$ cycles of a denaturation step at $95{ }^{\circ} \mathrm{C}$ for $15 \mathrm{~s}$, and an annealing/extension step at $60{ }^{\circ} \mathrm{C}$ for $60 \mathrm{~s}$. The amount of longicin expressions was divided by the amount of L23 expressions for both respective groups to obtain the normalized longicin expressions. Each sample was run in triplicates and the data were analyzed using the 7300 system SDS software (Applied Biosystems).

The percentage of gene silencing efficiency (\%) of ticks injected with longicin dsRNA compared to Luc dsRNAinjected ticks was calculated as follows: Gene silencing efficiency $(\%)=\left(1-\mathrm{L}_{\mathrm{Long}} / \mathrm{L}_{\mathrm{Luc}}\right) \times 100$. Where, $\mathrm{L}_{\mathrm{Long}}$ and $\mathrm{L}_{\mathrm{Luc}}$ represent the normalized longicin expressions of

Table $\mathbf{2}$ List of PCR primers used for the detection of longicin gene

\begin{tabular}{ll}
\hline Primer name & Primer sequence \\
\hline Longicin forward & ATGAAGGTCCTGGCTGTTGC \\
Longicin reverse & CTACTTGCGGTAGCACGTGC \\
HIB-actin forward & ATCCTGCGTCTCGACTTGG \\
HIß-actin reverse & GCCGTGGTGGTGAAAGAGTAG
\end{tabular}


Table 3 List of real-time PCR primers used for the determination of longicin gene silencing efficiency

\begin{tabular}{ll}
\hline Primer name & Primer sequence \\
\hline Longicin real-time forward & ACATGAAGGTCCTGGCTGTTG \\
Longicin real-time reverse & TCTCGTCATCTTGAGCTGCTG \\
L23 real-time forward & CACACTCGTGTTCATCGTCC \\
L23 real-time reverse & ATGAGTGTGTCACGTTGGC \\
\hline
\end{tabular}

longicin dsRNA-injected and Luc dsRNA-injected ticks, respectively [27].

Lastly, at 4 dai of longicin dsRNA, both longicin gene-silenced and Luc gene-injected ticks were challenged with LGTV (approximately $2.9 \times 10^{4} \mathrm{ffu} / 0.5 \mu \mathrm{l}$ ) via percoxal microinjection. Right after the challenge, the ticks were held for $18 \mathrm{~h}$ in a $25{ }^{\circ} \mathrm{C}$ incubator to check for mortality resulting from possible injury during injection. Thirty ticks per group were monitored for tick mortality for up to $35 \mathrm{dpi}$, while the remaining ticks per group were used for virus titration done at $0,1,3,7,14,21,28 \mathrm{dpi}$.

\section{Statistical analysis}

Data were statistically analyzed using Student's t-test wherein $P$ values less than 0.05 were regarded as significant. All samples were tested at least in triplicate.

The Mantel-Cox log-rank test was also performed using GraphPad Prism software to determine significant difference in mortality $(P<0.05)$ between control and longicin gene-silenced ticks challenged with LGTV.

\section{Results}

\section{Cytotoxicity activity of the longicin P4 peptide}

To eliminate the possibility that foci reduction was due to reduction in the number of viable host cells, we examined the cell growth inhibitory effect of partial peptides longicin P1 and P4 on BHK-21 cells (Fig. 1). Longicin P1 did not show any significant cytotoxicity on BHK-21 cells. In contrast, longicin P4 only demonstrated a non-significant cytotoxic effect at $1.25 \mu \mathrm{M}$ concentration. Based on these results, the $1.25 \mu \mathrm{M}$ concentration was used for both peptides in the succeeding tests.

\section{Antiviral effect of longicin P4 peptide against LGTV}

Since defensin molecules accumulate in microbial membranes resulting in formation of pores in the targeted membrane, we checked first the extracellular virucidal activity of longicin peptides against LGTV. As shown in Fig. 2a, co-incubation of $1.25 \mu \mathrm{M}$ longicin P4 with the virus at $37^{\circ} \mathrm{C}$ for $2 \mathrm{~h}$ reduced the number of fluorescencepositive viral foci which is equivalent to a $70 \%$ foci reduction (Fig. 2b). However, the same effect was not observed from longicin P1 treatment.

Likewise, to further support that longicin P4 has a virucidal activity against LGTV, we further checked if

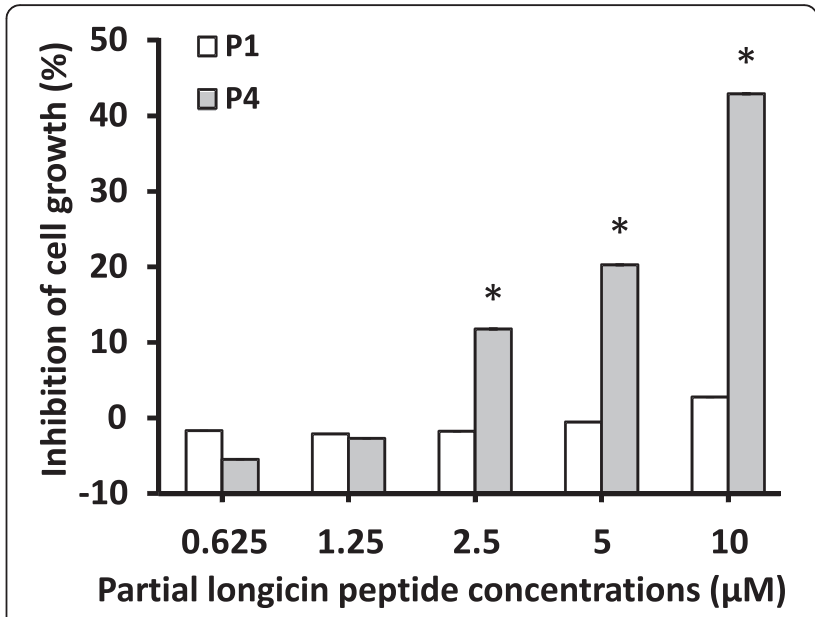

Fig. 1 Cytotoxicity of longicin P1 and P4 against BHK-21 cells. MTT assay was used to evaluate the cytotoxicity of the peptides. Values are representative of triplicate samples and error bars indicate the range of values obtained. ${ }^{*} p<0.05$, longicin P1 vs longicin P4

the longicin P4 can lower down the virus yield postinfection as compared to medium- and longicin P1treated LGTV. As shown in Fig. 2c, cells infected with virus treated with longicin $\mathrm{P} 4$ produced almost two-fold lower titer as compared to cells infected with either medium- or longicin P1-treated virus. Although the difference may seem low, the virus titer of longicin P4 group corresponds to more than $90 \%$ foci reduction in contrast to medium or longicin P1 treatment.

In addition, to further support that the possible mechanism of action of longicin P4 against LGTV is through extracellular virucidal activity and exclude alternative possibilities, we also conducted prophylactic and postadsorption antiviral assays. In the prophylactic antiviral assay, cells exposed to longicin P1 and P4 for two hours at $37{ }^{\circ} \mathrm{C}$ prior to virus infection showed statistically nonsignificant foci reduction at 0.76 and $-1.820 \%$, respectively (Fig. 3a). Similarly, no significant antiviral activity was also recorded for both longicin peptides against LGTV in the post-adsorption antiviral assay, wherein, longicin P1 and P4 showed 0.71 and $4.4 \%$ foci reduction, respectively (Fig. 3b).

Moreover, after establishing that co-incubation of longicin P4 with LGTV can successfully reduce foci formation and virus yield, we then checked the dose-dependent and time-dependent virucidal capacity of longicin P4. As shown in Fig. 4a, $1.25 \mu \mathrm{M}$ of longicin P4 can significantly produce more than $50 \%$ foci reduction against LGTV, while the lowest concentration to show a significant foci reduction was $0.65 \mu \mathrm{M}$. Likewise in Fig. $4 \mathrm{~b}$, we can also observe that before adding to the cells, at least $30 \mathrm{~min}$ of close contact between the virus and longicin $\mathrm{P} 4$ at $37{ }^{\circ} \mathrm{C}$ is required to achieve significant foci reduction and the optimum virucidal activity can be achieved at $2 \mathrm{~h}$ treatment. 


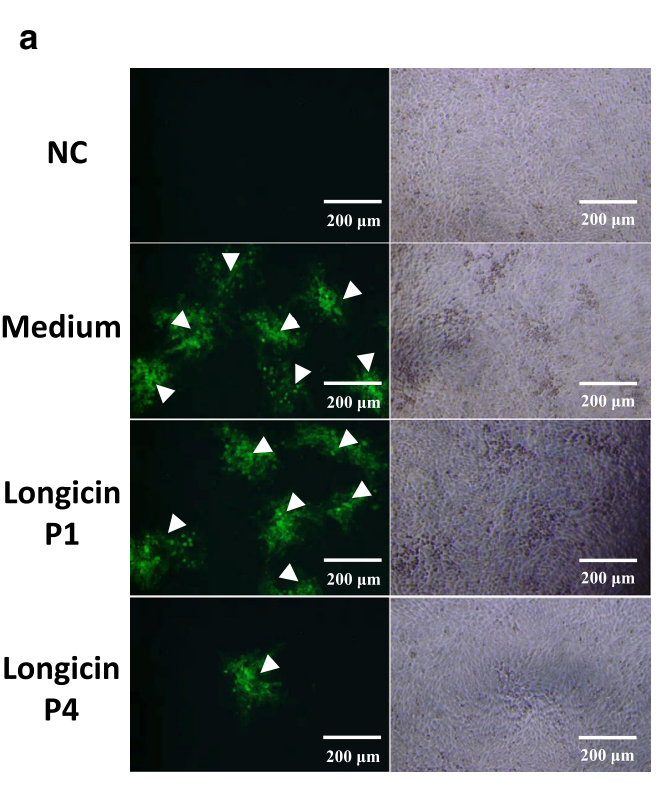

b

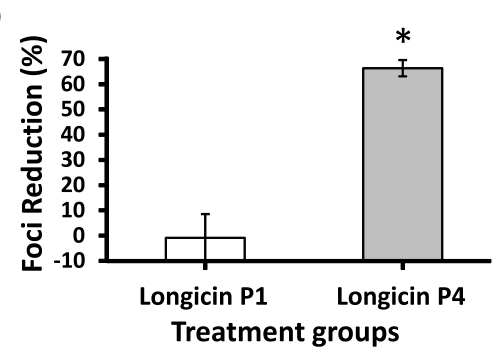

C

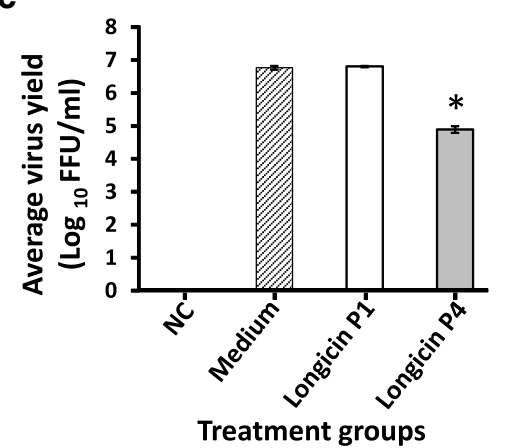

Fig. 2 Virucidal effect of longicin P1 and P4 against Langat virus. a Fluorescence images of BHK-21 cells infected with Langat virus (TP-21) treated with medium only, $1.25 \mu \mathrm{M}$ of P1 and P4 for $2 \mathrm{~h}$ at $37^{\circ} \mathrm{C}$. Arrowheads point to positive fluorescence FFU. $\mathbf{b}$ Foci reduction and $\mathbf{c}$ yield reduction assays were used to determine extracellular virucidal effect of longicin peptides. The percentage of foci reduction (\%) was obtained by comparing against medium-treated cells maintained in parallel. All experiments were conducted in triplicates and error bars indicate the range of values. NC refers to cells with no treatment and no infection. ${ }^{*} p<0.05$, longicin P4 vs longicin P1 or medium

\section{Antiviral effect of longicin P4 peptide against human adenovirus}

Our results showed that longicin P4 has a virucidal activity against LGTV and it is supported by previous findings that suggest that cationic antimicrobial peptides such as longicin P4 can only target pathogens possessing a membrane $[10,11]$. Thus, to check if longicin P4 can only exert antiviral activity against membrane-bound or enveloped viruses, we determined its virucidal activity against a non-
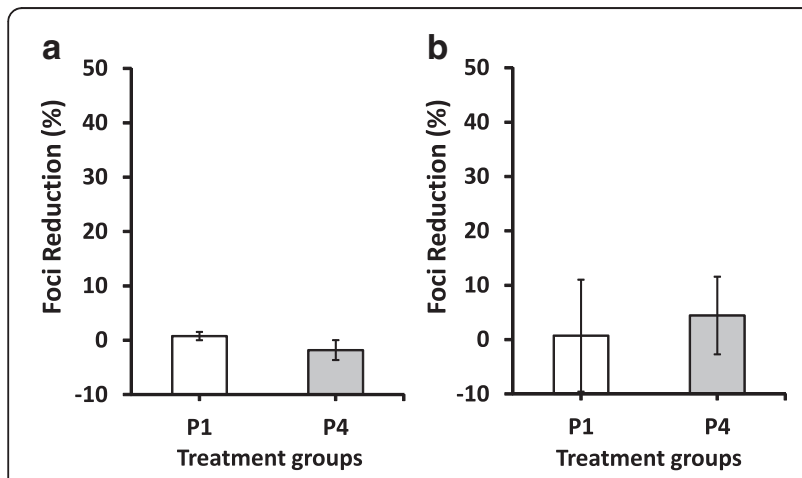

Fig. 3 Prophylactic (a) and post-adsorption (b) antiviral effects of longicin P1 and P4 against Langat virus. Experiments were conducted in triplicates and error bars indicate the range of values. The percentage of foci reduction (\%) was obtained by comparing against medium-treated cells maintained in parallel. ${ }^{*} p<0.05$, longicin P4 vs longicin P1 or medium enveloped virus. As shown in Fig. 5a, co-incubation of $1.25 \mu \mathrm{M}$ of longicin P4 and P1 failed to reduce adenovirus infectivity leading to a successful viral infection and marked cell death. In addition, no significant difference can be observed in the virus yield from medium-, P1- and P4-treated adenovirus (Fig. 5b).

\section{Effect of longicin gene silencing in LGTV replication in adult $\boldsymbol{H}$. longicornis}

To evaluate the importance of longicin in the innate immunity of $H$. longicornis adult ticks against LGTV,

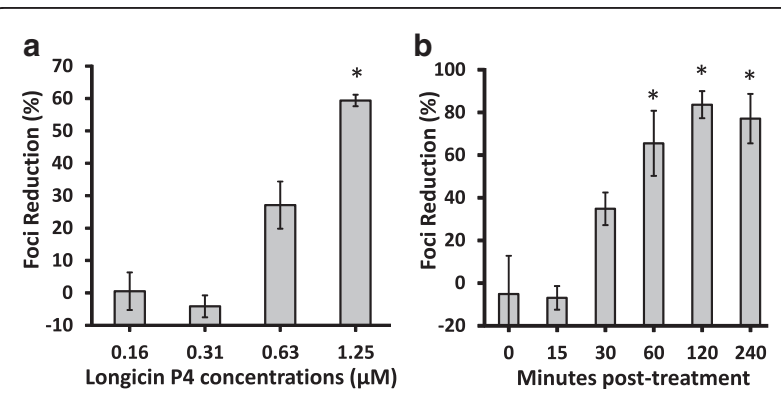

Fig. 4 Dose-dependent (a) and time-dependent (b) virucidal effects of longicin P4 against Langat virus. Experiments were conducted in triplicates and error bars indicate the range of values. The percentage of foci reduction (\%) was obtained by comparing against mediumtreated cells maintained in parallel. ${ }^{*} p<0.05$, as compared to the lowest concentration or to 0 min 


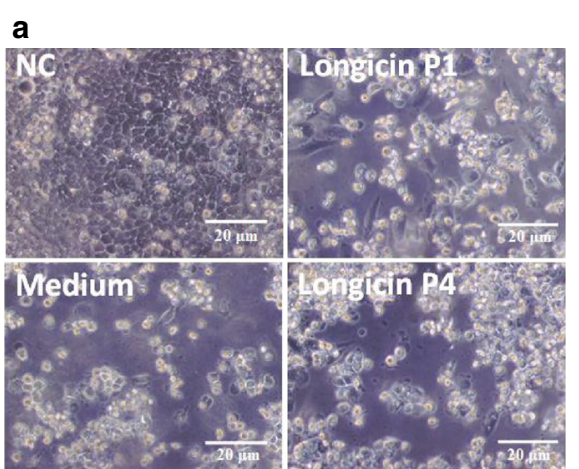

\section{b}

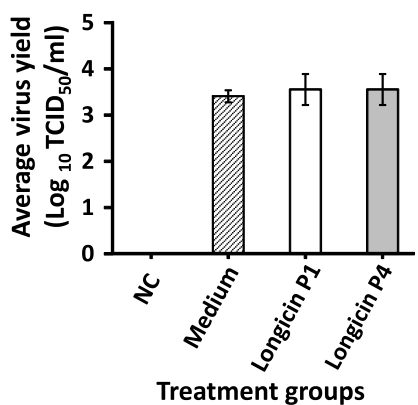

Fig. 5 Virucidal activity of longicin P1 and P4 against adenovirus. a Images of HeLa cells infected with human adenovirus 25 treated with medium only, $1.25 \mu \mathrm{M}$ of longicin P1 and P4 for $2 \mathrm{~h}$ at $37^{\circ} \mathrm{C}$. Images were taken $7 \mathrm{dpi}$ (200xmagnification). $\mathbf{b}$ TCID 50 was used to determine the virus yield titers of the collected supernatants of the treatment groups. Data expressed as means \pm SD

gene silencing through RNAi was performed. Ticks were individually injected with either longicin dsRNA or with Luc dsRNA for the control group. Silencing of longicin gene was confirmed visually by regular RT-PCR and gel electrophoresis (Fig. 6a). In addition, gene silencing efficiency was also determined using real-time PCR (Fig. 6b), wherein more than $90 \%$ of longicin mRNA reduction can be observed for at least 60 days after microinjection of longicin dsRNA.

Although mean virus titers from whole ticks (Fig. 6c) demonstrate significant differences at 7 and $21 \mathrm{dpi}$ between longicin dsRNA and Luc dsRNA injected ticks, the titers for both groups eventually equalized at the end of the observation period. In addition, no significant difference was observed in tick mortality on both groups after 35 dpi (Fig. 6d).

\section{Discussion}

Several studies have already shown the antimicrobial, fungicidal, and parasiticidal activities of longicin and one of its synthetic partial analogs (longicin P4). A previous study has shown that some known defensins have a common motif $\left(G^{3} R R G G^{5}\right)$ which could be related to their antiparasitic activity [28]. Such motif was also found in longicin P4 suggesting that this motif is the one responsible for its antiparasitic activity $[15,29]$. Since longicin P4 has been shown to possess antimicrobial, fungicidal, and parasiticidal properties, we decided

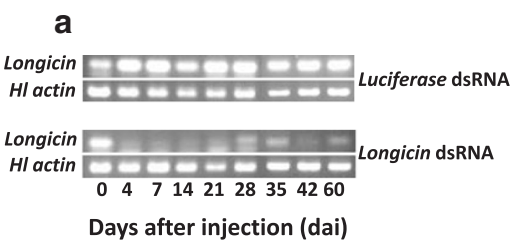

C

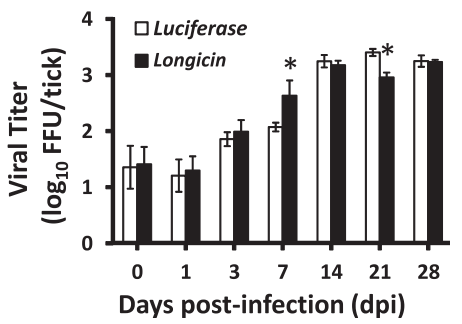

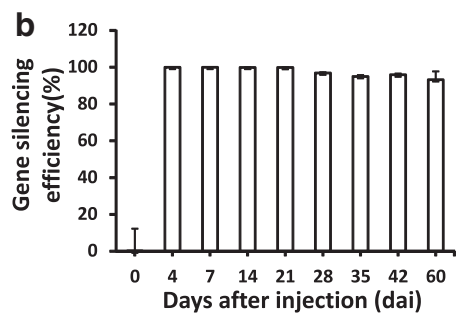

d

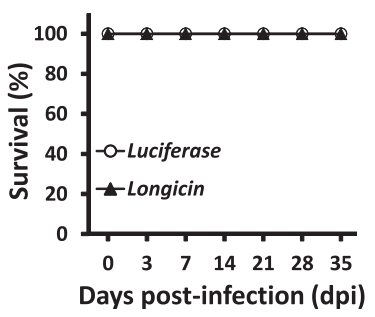

Fig. 6 Effect of longicin silencing in tick mortality and virus titer. a To confirm gene-specific silencing, 3 ticks from each group were collected at 0 , $4,7,14,21,28,35,42$ and 60 dai of dsRNA. Initial confirmation of longicin silencing was carried out through RT-PCR and gel electrophoresis (a), while gene silencing efficiency was determined by real-time PCR (b). Virus titers (c) and tick survival (d) were monitored after injecting LGTV on 4-day luciferase dsRNA- or longicin dsRNA-inoculated ticks. Values for mortality ( $n=30$ ticks per group) were expressed as the percentage of live ticks remaining to the number of ticks used at the beginning of the experiment in different time courses. Significant difference $\left({ }^{*} p<0.05\right)$ was determined using the Mantel-Cox log-rank test, while error bars in virus titers indicate SD in mean values of 5 ticks. ${ }^{*} p<0.05$, luciferase vs longicin 
to test the peptide for its antiviral activity against a tickborne flavivirus.

In this study, our data show that co-incubation treatment of LGTV with longicin P4 at $1.25 \mu \mathrm{M}$ concentration prior to infection resulted in significant foci reduction. And to clarify if this antiviral activity is also present in the full-length (FL) longicin peptide, we also checked the antiviral capacity of the FL longicin against LGTV. Initially, we determined first the non-cytotoxic concentration of FL longicin on BHK cells (see Additional file 1a) and used this concentration as the treatment concentration. As expected, FL longicin also exhibited an almost $40 \%$ viral foci reduction (see Additional file 1b).

On the other hand, the virus yield from cells infected with virus co-incubated with longicin P4 produced lower titer as compared to cells infected with either medium or longicin P1 treated virus, resulting in more than $90 \%$ foci reduction as compared to medium or longicin P1 treatment.

The lower virus yield from cells infected with virus coincubated with longicin P4 further confirm that the virucidal activity of longicin P4 is extracellular, through close contact, as previously shown in another study that longicin P4 impairs parasite membranes (Toxoplasma gondii) resulting in the reduction of infection in cells [15]. In addition, the failure of longicin P4 to significantly reduce foci formation in the prophylactic and post-adsorption antiviral assays clearly supports that the antiviral activity of the peptide is exerted through extracellular inactivation of the virus particle.

LGTV, being an enveloped virus, has an outer coating that is composed of a lipid bilayer. Viral envelope can be a target for longicin as defensin molecules accumulate in microbial membranes resulting in the formation of pores in the targeted membrane [30]. However, additional experiments to show the binding between extracellular virus and longicin P4 are needed to fully establish the exact mechanism of membrane targeting of longicin in enveloped viruses. Nevertheless, to confirm that the effect of longicin P4 may only be limited to membranebound targets, a common trait for cationic antimicrobial peptides, we tested its virucidal activity against human adenovirus 25, a non-enveloped virus. As shown in Fig. 5, longicin P4 failed to inhibit virus replication, thus supporting the claims that although cationic antimicrobial peptides have diverse targets, their activity is generally limited to targets with membranes [11, 29].

However, previous findings by Smith and Nemerow [31], showed that human $\alpha$-defensin can inhibit adenovirus infection by directly binding to non-enveloped adenoviral capsid, inhibiting virus disassembly. Such binding ultimately leads to inhibition of endosomal membrane penetration during cell entry. This finding further explains that the virucidal activity of longicin P4 may only be limited to enveloped viruses and the synthetic peptide does not target the capsid of adenovirus. Likewise, it is also possible to suppose that longicin P4 can directly bind on the membrane of LGTV without disrupting the viral envelope, and in effect inhibits the binding of the virus to cellular receptors for viral entry. However, this mechanism remains to be elucidated.

Lastly, to fully elucidate the importance of longicin in the innate immunity of $H$. longicornis ticks against LGTV, gene silencing through RNAi was performed. After successfully silencing the longicin gene, ticks were challenged with LGTV via microinjection. Preliminary results on the effect of longicin gene silencing on virus titer show that significant difference can be observed at 7 and $21 \mathrm{dpi}$. At $7 \mathrm{dpi}$, longicin gene-silenced ticks produced higher viral titer as compared to luc dsRNA injected ticks, which may be attributed to longicin gene silencing. However, at 21 dpi, longicin gene-silenced ticks showed lower viral titer as compared to the control. Although a relatively high gene silencing efficiency (more than $90 \%$ ) can be observed for at least 60 dai, the lower viral titer in the longicin gene-silenced group at $21 \mathrm{dpi}$ remains to be answered, thus suggesting that the effect of longicin gene silencing on the survival dynamics of LGTV in vivo still remains unclear. In addition, a complete knockdown of the longicin gene may also be needed to fully assess the function of longicin against LGTV in vivo.

On the other hand, for the whole duration of the study, no significant difference in mortality was observed on both longicin gene-silenced and Luc dsRNA-injected ticks. Failure to observe any significant effect on tick mortality on the longicin-silenced ticks, may suggest that the activity of longicin in the tick is not related to the control LGTV infection or the virus model used for this study may not be suitable to test our hypothesis. Likewise, the sturdiness of ticks against any harmful effect due to LGVT infection may be expected since ticks act as highly efficient reservoirs of flaviviruses [32]. Moreover, the failure of longicin silencing to affect the tick's resistance to LGTV suggests that the peptide's activity may only be effective in vitro. As previously observed, activities of antimicrobial peptides can be undesirably affected by various relevant factors present in vivo and these may include proteases, polyanions and high mono- and divalent cation concentrations [12].

\section{Conclusion}

In summary, we have successfully established the extracellular virucidal activity of longicin P4 against LGTV in vitro, and to our knowledge, this is the first report of an antiviral activity of a native or synthetic antimicrobial peptide derived from $H$. longicornis. However, the role of the endogenous tick longicin in the antiviral defense of $H$. longicornis still remains to be demonstrated. 


\section{Additional file}

Additional file 1: Virucidal effect of full-length (FL) longicin against LGTV. Foci reduction assay was used to determine the extracellular virucidal effect of baculovirus-expressed FL longicin peptide using $0.5 \mathrm{~nm}$ concentration. Based from the cell proliferation assay (a), $0.5 \mathrm{nM}$ of FL longicin showed no significant cytotoxicity on BHK cells that may affect the result of the foci reduction assay. (b) The percentage of foci reduction (\%) was obtained by comparing against medium-treated cells maintained in parallel. All experiments were conducted in triplicates and error bars indicate the range of values. (PDF $109 \mathrm{~kb}$ )

\section{Abbreviations}

dsRNA: double-stranded RNA; Luc: firefly luciferase; PBS: phosphate buffered saline; RNAi: RNA interference.

\section{Competing interests}

The authors declare that they have no competing interests.

\section{Authors' contributions}

MRT, TT, and MM designed the experiments. MRT, RLG, HM, EPH, and KK performed the experiments. MRT, KY, NT, KF, T, and MM analyzed the data MRT wrote the manuscript. All the authors checked and approved the final version of the manuscript to be published.

\section{Acknowledgments}

This study was supported by the Japan Society for the Promotion of Science (JSPS) KAKENHI Grant Numbers 25292173, 26660229 and $15 \mathrm{H05264}$ and the Japanese Government Ministry of Education, Culture, Sports, Science, and Technology Scholarship (Monbukagakusho: MEXT) for doctoral fellowship. We would also like to thank Dr. Takahiro Kusakabe and Dr. Jae Man Lee from the Laboratory of Silkworm Science, Faculty of Agriculture of Kyushu University and Dr. Takeshi Miyata from the Laboratory of Food Chemistry, Department of Biochemistry and Biotechnology, Division of Molecular Function of Food, Faculty of Agriculture of Kagoshima University for providing the baculovirus-expressed full-length longicin peptide and Dr. Tatsunori Masatani of Joint Faculty of Veterinary Medicine, Transboundary Animal Diseases Center of Kagoshima University for the HeLa cells.

\section{Author details}

'Department of Pathological and Preventive Veterinary Science, The United Graduate School of Veterinary Science, Yamaguchi University, Yoshida, Yamaguchi 753-8515, Japan. ' Laboratory of Infectious Diseases, Joint Faculty of Veterinary Medicine, Kagoshima University, 1-21-24 Korimoto, Kagoshima 890-0065, Japan. 'ªboratory of Public Health, Graduate School of Veterinary Medicine, Hokkaido University, Kita-ku kita-18 nishi-9, Sapporo, Hokkaido 060-0818, Japan. ${ }^{4}$ Department of Parasitology, Kitasato University School of Medicine, 1-15-1 Kitasato, Minami, Sagamihara, Kanagawa 252-0374, Japan. ${ }^{5}$ Zen-noh Institute of Animal Health, Ohja, Sakura, Chiba 285-0043, Japan. ${ }^{6}$ Department of Clinical and Population Health, College of Veterinary Medicine and Biomedical Sciences, Cavite State University, Cavite 4122, Philippines. ${ }^{7}$ Department of Veterinary Paraclinical Sciences, College of Veterinary Medicine, University of the Philippines Los Baños, Los Baños, Laguna 4031, Philippines.

Received: 30 November 2015 Accepted: 26 January 2016 Published online: 02 February 2016

\section{References}

1. de la Fuente J, Estrada-Pena A, Venzal JM, Kocan KM, Sonenshine DE. Overview: Ticks as vectors of pathogens that cause disease in humans and animals. Front Biosci. 2008;13:6938-46.

2. Hajdušek O, Síma R, Ayllón N, Jalovecká M, Perner J, de la Fuente J, et al. Interaction of the tick immune system with transmitted pathogens. Front Cell Infect Microbiol. 2013;3:26.

3. Jongejan F, Uilenberg G. The global importance of ticks. Parasitology. 2004;129:S3-14.

4. Yeung AT, Gellatly SL, Hancock RE. Multifunctional cationic host defence peptides and their clinical applications. Cell Mol Life Sci. 2011;13:2161-76.
5. Tsuji N, Battsetseg B, Boldbaatar D, Miyoshi T, Xuan X, Oliver JHJ, et al. Babesial vector tick defensin against Babesia sp. parasites. Infect Immun. 2007;75:3633-40.

6. Nakajima Y, Taylor D, Yamakawa M. Involvement of antibacterial peptide defensin in tick midgut defense. Exp Appl Acarol. 2002;1:135-40.

7. Tonk M, Cabezas-Cruz A, Valdés JJ, Rego RO, Chrudimská T, Strnad M, et al. Defensins from the tick Ixodes scapularis are effective against phytopathogenic fungi and the human bacterial pathogen Listeria grayi. Parasit Vectors. 2014;7:554

8. Tang YQ, Yuan J, Osapay G, Osapay K, Tran D, Miller CJ, et al. A cyclic antimicrobial peptide produced in primate leukocytes by the ligation of two truncated alpha-defensins. Science. 1999:5439:498-502.

9. Bulet P, Hetru C, Dimarcq J, Hoffmann D. Antimicrobial peptides in insects; structure and function. Dev Comp Immunol. 1999:4-5:329-44.

10. Zasloff M. Antimicrobial peptides of multicellular organisms. Nature. 2002:415:389-95.

11. De Smet K, Contreras R. Human antimicrobial peptides: defensins, cathelicidins and histatins. Biotechnol Lett. 2005;18:1337-47.

12. Hancock REW, Diamond G. The role of cationic antimicrobial peptides in innate host defences. Trends Microbiol. 2000;2000:402-10.

13. Hilchie AL, Wuerth $\mathrm{K}$, Hancock RE. Immune modulation by multifaceted cationic host defense (antimicrobial) peptides. Nat Chem Biol. 2013;12:761-8.

14. Rahman M, Tsuji N, Boldbaatar D, Battur B, Liao M, Umemiya-Shirafuji R, et al. Structural characterization and cytolytic activity of a potent antimicrobial motif in longicin, a defensin-like peptide in the tick Haemaphysalis Iongicornis. J Vet Med Sci. 2010;72:149-56.

15. Tanaka T, Maeda H, Matsuo T, Boldbattar D, Umemiya-Shirafuji R, Kume A, et al. Parasiticidal activity of Haemaphysalis longicornis longicin P4 peptide against Toxoplasma gondii. Peptides. 2012;34:242-50

16. Reddy KVR, Yedery RD, Aranha C. Antimicrobial peptides: premises and promises. Int J Antimicrob Agents. 2004;24:536-47.

17. Mlera L, Offerdahl DK, Martens C, Porcella SF, Melik W, Bloom ME. Development of a model system for tick-borne flavivirus persistence in HEK 293 T cells. MBio. 2015:3:614-5.

18. Weber E, Finsterbusch K, Lindquist R, Nair S, Lienenklaus S, Gekara NO, et al. Type I interferon protects mice from fatal neurotropic infection with Langat virus by systemic and local antiviral responses. J Virol. 2014;21:12202-12.

19. Lindquist L, Vapalahti O. Tick-borne encephalitis. Lancet. 2008:9627:1861-71.

20. Zandi K, Teoh BT, Sam SS, Wong PF, Mustafa MR, Abubakar S. In vitro antiviral activity of fisetin, rutin and naringenin against dengue virus type-2. Jed Plants Res. 2011;23:5534-9.

21. Ashley SL, Welton AR, Harwood KM, Rooijen NV, Spindlera KR. Mouse adenovirus type 1 infection of macrophages. Virology. 2009;2:307-14.

22. Reed $\amalg$, Muench $\mathrm{H}$. A simple method of estimating fifty percent endpoints. Am J Hyg. 1938;27:493-7.

23. Zandi K, Teoh BT, Sam SS, Wong PF, Mustafa MR, Abubakar S. Novel antivira activity of baicalein against dengue virus. BMC Complement Altern Med. 2012:12:214

24. Altmann SE, Brandt CR, Jahrling PB, Blaney JE. Antiviral activity of the EB peptide against zoonotic poxviruses. Virol J. 2012;9:6.

25. Galay RL, Aung KM, Umemiya-Shirafuji R, Maeda H, Matsuo T, Kawaguchi H, et al. Multiple ferritins are vital to successful blood feeding and reproduction of the hard tick Haemaphysalis longicornis. J Exp Biol. 2013:216:1905-15.

26. Maeda H, Miyata T, Kusakisako K, Galay RL, Talactac MR, Umemiya-Shirafuji R, et al. A novel C-type lectin with triple carbohydrate recognition domains has critical roles for the hard tick Haemaphysalis longicornis against Gram-negative bacteria. Dev Comp Immunol. 2015. doi:10.1016/j.dci. 2015.12.015

27. Yamada $Y$, Suzuki R, Harashima H. Investigation of siRNA nanoparticle formation using mono-cationic detergents and its use in gene silencing in human HeLa cells. Cancers. 2013;5:1413-25.

28. Gao B, Rodriguez MC, Lanz-Mendoza H, Zhu S. AdDLP, a bacterial defensin-like peptide, exhibits anti-plasmodium activity. 2008, 45:3909-3916. Biochem Biophys Res Commun. 2009:387:393-8.

29. Tian C, Gao B, Rodriguez MC, Lanz-Mendoza H, Ma B, Zhu S. Gene expression, antiparasitic activity, and functional evolution of the drosomycin family. Mol Immunol. 2008;45:3909-16. 
30. Chen $H, X u Z$, Peng L, Fang $X$, Yin $X, X u N$, et al. Recent advances in the research and development of human defensins. Peptides. 2006;4:931-40.

31. Smith JG, Nemerow GR. Mechanism of adenovirus neutralization by human a- defensins. Cell Host Microbe. 2008;1:11-9.

32. Nuttall PA, Labuda M. Dynamics of infection in tick vectors and at the tickhost interface. Adv Virus Res. 2003;60:233-72.

Submit your next manuscript to BioMed Central and we will help you at every step:

- We accept pre-submission inquiries

- Our selector tool helps you to find the most relevant journal

- We provide round the clock customer support

- Convenient online submission

- Thorough peer review

- Inclusion in PubMed and all major indexing services

- Maximum visibility for your research

Submit your manuscript at www.biomedcentral.com/submit 